\title{
Effects of Cooperative Learning on Grade 11 Students' Writing Performance: Afar Regional State, Ethiopia
}

\author{
Mitiku Teshome Abeti ${ }^{1}$, Italo Beriso ${ }^{2}$ \\ ${ }^{1}$ English Language and Literature, Samara University, Samara, Ethiopia \\ ${ }^{2}$ Department of Foreign Languages and Literature, Addis Ababa University, Addis Ababa, Ethiopia
}

Email address:

mitshalove@yahoo.com (M. T. Abeti), italo.beriso@aau.edu.et (I. Beriso)

\section{To cite this article:}

Mitiku Teshome Abeti, Italo Beriso. Effects of Cooperative Learning on Grade 11 Students' Writing Performance: Afar Regional State, Ethiopia. Arabic Language, Literature \& Culture. Vol. 6, No. 2, 2021, pp. 26-36. doi: 10.11648/j.allc.20210602.11

Received: February 23, 2021; Accepted: April 16, 2021; Published: May 8, 2021

\begin{abstract}
This study was an attempt to investigate the effects of cooperative learning on Grade 11 students' writing performance in Afar Regional State, Samara Secondary and Preparatory School, in focus. More specifically, the study addressed the following research questions: (1) What are the effects of cooperative learning on students' writing performance? (2) Which one of the components of writing most benefited from the cooperative learning approach? And the following hypotheses: (Ho) There is no significant difference in the mean gain scores of the writing performance before and after the incorporation of cooperative learning and (H1) There is a significant difference in the mean gain scores of the writing performance before and after the incorporation of cooperative learning. This research project was mainly experimental in design. Pre-test and post-test measures were analyzed using a t-test statistical procedure. The main subjects of the study were two sections of Grade 11 students. Moreover, 60 students, 30 each from two natural science classes were randomly grouped as experimental and control groups. The effects of CL on students' writing ability was examined through the pre-test and the posttest. The results of the pre-test showed that there was no significant difference in the students' writing between the control and experimental groups prior to the experiment. The results of the post-test showed that there was a significant difference between the control and experimental groups in students' writing abilities $(\mathrm{P}<0.05)$. Therefore, the null hypothesis was rejected and the alternative hypothesis was proved to bring change on students' writing ability. Similarly, the study also identified that organization is the basic component of writing skill that benefited most from the cooperative learning approach. However the current study was showed positive effects of CL on students' writing performance, in the future researches can be conducted on the effects of CL on other language skills.
\end{abstract}

Keywords: Cooperative Learning, Writing Skills, Cooperative Writing, Individual Writing, Writing Performance, Components of Writing

\section{Introduction}

The Afar National Regional State of the Federal Democratic Republic of Ethiopia is astronomically located from $8^{\circ} 49^{\prime} \mathrm{N}$ to $14^{\circ} 30^{\prime} \mathrm{N}$ latitude and from $39^{\circ} 34^{\prime} \mathrm{E}$ to $42^{\circ} 28^{\prime} \mathrm{E}$ longitude. Situated at the Northeastern part of Ethiopia, the Afar Region is entirely found within the Great East African Rift Valley System. The region shares international boundaries with Eritrea in the north-east and Djibouti in the east. It also shares borders with the Regional States of Tigray, Amhara, Oromia and Somali in the northwest, south-west, south and south-east respectively.

Administratively, the Afar National Regional State is sub- divided into 5 administrative zones, 32 'weredas' and 401 rural and urban 'kebeles'. The Constitution of the Afar National Regional State (ANRS, 2000), recognizes 'weredas' as autonomous with clearly defined power and functions. Cognizant of this, the 'wereda' system had been laid down before two decades and power is now being devolved upon the 'wereda' structures.

The total population of the Afar Region is estimated to be about 1.4 million people (CSA, 2008). The majority of the population $(87 \%)$ are rural mainly dependent on pastoral and agro-pastoral livelihood systems. In terms of sex 
composition, male constitute $57 \%$ while the remaining $43 \%$ are females. With an estimated area of about 94,885 square kilometer, the region has an estimated population density of about 15 people per square kilometer.

\subsection{Statement of the Problem}

Despite the importance of writing skills in students' life in and after school, little attention has been given to such skills. For instance, ItaloBeriso [36] states, "There seems to be a general tendency amongst language teachers (in Ethiopia) to relegate writing to homework or avoid it altogether." Similarly, Alamirew G/Mariam [1] reports, "Writing is not effectively taught in the high schools. The teachers do not teach writing properly, that is, they do not give attention to the teaching of writing." To bring a change in attitude and practice of teaching writing in Ethiopian high schools, many things can be done towards driving suitable teaching methods and techniques that promotes students' writing skill.

One of the approaches which show positive result in boosting the students' writing skill is the incorporation of cooperative learning Kagan and High [49]. Studies also show that there are three major positive impacts of cooperative learning which are categorized into greater effort to achieve, more positive relationship among pupils and greater psychological health Johnson and Johnson [39]. Thus, this research will contribute to the existing body of literature by investigating the effects of using cooperative learning with a group of adolescent learners in an Ethiopian secondary and preparatory school context. It will focus on the effects of using cooperative learning in developing the students' writing skill.

Teaching writing by using cooperative learning approach has been conducted by some researchers internationally and locally that tried to promote it to be used in classroom setting in teaching English language. Internationally, teaching writing by using cooperative learning has been conducted by some researchers such as Norman, Tsailing and Harmer. Norman [25] conducted the study of cooperative learning with the students in grade five and six at Yangeun Elementary School in Busan, South Korea. They studied the influence of cooperative learning toward students' achievement, motivation, and attitudes. The result of his study shows that cooperative learning has positive effects for teaching writing because cooperative learning can motivate the students to work together in the learning process. Another researcher who conducted the study of teaching writing by using cooperative learning is Tsailing [54] who made her research on Implementing Cooperative Learning in EFL Teaching: Process and Effect in 2002. She focused on the process and effect of cooperative learning in two classes of the first year Junior High School students in a rural town in central Taiwan. Her study found out that the cooperative learning created positive environment and gave the students opportunities, freedom, and interaction in the classroom because cooperative learning created more friendly and supportive learning environment within which students had more opportunities and enjoyed more freedom to explore and practice the target language in writing process. Similarly, Harmer [26] states that group writing allowed the lecturer to give more detailed and constructive feedback since he was dealing with small number of groups rather than many individual students. Individual students also found themselves saying and writing things they might not have come up with on their own and the group's research was broader than an individual's normally was.

As the importance of English in our country for both education and communication is increasing, conducting research into the quality of teaching and learning of English is vital. Specially, studies related to reading and writing appears to be more important than other skills in helping students use these skills in their studies. To pass their courses successfully or to write essays of different kinds effectively, reading and writing skills help them a lot.

The researcher is, hence, motivated to conduct this study because of the failure to use cooperative learning to teach writing skills by EFL teachers as far as my experience is concerned and the absence of any experimental study to test the effects of cooperative learning in EFL classrooms in preparatory schools in Ethiopian context amongst the literatures and researches I have read through. Therefore, the present researcher attempted to examine the effects whether it brings a change or not. In addition, the researcher also investigated which components of writing most benefited from the cooperative learning approach. Thus, this study was aimed to answer the following basic research questions.

\subsection{Research Questions}

The research questions proposed in this study are:

What are the effects of cooperative learning on students' writing performance?

Which one of the components of writing benefits most from the cooperative learning approach?

\subsection{Research Hypotheses}

The research hypotheses of this study are:

Ho: There is no significant difference in the mean gain scores of the writing performance before and after the incorporation of cooperative learning.

H1: There is a significant difference in the mean gain scores of the writing performance before and after the incorporation of cooperative learning.

\subsection{Objectives of the Study}

The general objective of the study is to investigate the effects of cooperative learning on students' writing performance in EFL classes.

The specific objectives are to:

Investigate the effects of cooperative learning on students' writing performance,

Identify the component of writing that benefits most from the cooperative learning approach. 


\section{Reviewing a Literature}

\subsection{Definition of Cooperative Learning}

There are many claims about pupils working together cooperatively. Indeed, seating children in small groups is common practice in UK classrooms [19], but this, of course, may not mean they are cooperating. Thus, it is important to be clear about the defining features of cooperative learning.

Regarding its application to classroom, Cohen [9] defined cooperative learning as "Students working together in a group small enough that everyone can participate on a collective task that has been clearly assigned. Moreover, students are expected to carry out their task without direct and immediate supervision of the teacher."

This indicates that cooperative learning is a broad concept with a range of methods; the key factor being that pupils are placed in small groups and help one another with academic tasks. Similarly, Johnson and Johnson [43] also state simply that 'cooperation is working together to accomplish shared goals'. The key aspects concern joint working with a shared purpose. Therefore, the definition of cooperative learning underpinning this research will therefore be: pupils working together in small groups on a joint task which ensures interdependence and interaction.

\subsection{Elements of Cooperative Learning}

Built upon the Johnsons findings, Sclater and Bolander [22] assert that "it is not enough to place students together in groups and expect them to work together." Consequently, advocates of CL believe that this set of teaching principles can actually take place and be best effective only if certain conditions are afforded. Johnson, Johnson and Holubec [41] suggest five elements, which they call "the essential components of cooperation", that should be present to consider a teaching instruction as CL; positive interdependence, face-to-face promotive interaction, individual accountability, interpersonal and small group skills, and group processing. These elements should be structured altogether in order to obtain satisfactorily positive results.

\subsubsection{Positive Interdependence}

Positive interdependence is regarded as the first and most important element to structure CL where students work toward a common goal together and rely on each other to succeed, each performing an individual focal role for the end product to be positive. Johnson and Johnson (1999; cited in Gillies et al., [21] argue that positive interdependence occurs when "individuals realize that their efforts are required in order for the group to succeed so that it is not possible to get a free-ride."

In other words, this component underlies students' perception of the fact that they are related to one another in some way in which the participant in a group cannot succeed unless his/her team-mates succeed -the benefit is a two-way process. Group members are positively interdependent and have a specific contribution to the success of the whole group due to the shared resources, common goals, mutual support, and the celebration of the joint reward. When there is high positive interdependence among the group mates, there will be better performance in their writing.

\subsubsection{Face-to-Face Promotive Interaction}

Positive interdependence creates promotive interaction. The latter takes place when "individuals encourage and facilitate each other's efforts to accomplish the group's goals" Gillies [21]. This component promotes the group participants' productivity of the foreign language and achievement when each of them gives and receives effective help, assistance and feedback; exchanges explanations; and challenges each other's way of thinking through acting trustfully, being motivated for mutual benefit, influencing efforts to achieve common goals and encouraging one another.

\subsubsection{Individual Accountability}

Though participants in a cooperative group join their abilities and work together for the benefit of all the members, "each student needs to be made accountable for his/her own contribution to the completion of the task" Ellis, [18]. Members are responsible for completing their part of the task and for assisting their partners complete their share of the work. If learners perceive that their performance will affect the group's outcomes, they will produce more efforts to realize their objectives. Thus, the performance or the quality and the quantity of each member's contributions are assessed and evaluated separately, and the result is reported to the individual and the group to determine who is in need of more assistance, support and encouragement. Since individual accountability has proved to increase students' academic achievement and to improve their performance when they feel that their efforts are taken into consideration, teachers have to structure ways which help them assess each participant individually.

\subsubsection{Interpersonal and Small Group Skills}

This is a basic element which promotes higher achievement and, more importantly, builds positive relationships among students; both on a personal and professional level (Gillies et al., [21]. Crandall [7] believes that, in order for a group of students who cooperate together striving towards attaining a shared goal successfully, "individual members need to develop not only linguistic but also social skills which facilitate teamwork, create trust and enhance communication, leadership, problem solving and decision-making in group interaction." Moreover, Slavin [67] adds that individuals must have or be taught the social and cooperative skills necessary to interact effectively with peers and, hence, produce more. They are trained how to get to know and trust each other, how to negotiate viewpoints and respect diverse opinions, how to resolve disagreements and differences positively, and how to encourage and help each other (Gillies et al., 2008).

\subsubsection{Group Processing}

Ngeow (2000), cited in Roberts (2004), asserts that groups 
need time to evaluate their goals and discuss how well the group participants are progressing and maintaining effective working relationships. On the other hand, Johnson and Johnson (1999; cited in Gillies et al., [21] contend that teachers should devote some time at the end of each session to give learners the chance to: "(a) describe what member actions were helpful and unhelpful and (b) make decisions about what actions to continue or change." In other words, they reflect upon their experience as a cooperative group to determine what was positive in their way of handling the task and to modify and ameliorate what was less helpful as behavior in their joint work.

\subsection{Basic Components of Writing}

There are different components of writing that make writing more effective and powerful. Amongst the components, the current study focuses on organization, grammar, content, vocabulary, coherence and cohesion and mechanics of writing. The following are the details.

\subsubsection{Organization}

This element of writing has to do with coherent arrangement of material. It involves keeping the reader oriented to the central and subordinate ideas. Good organization is logical and sequential. It guides the reader between divisions of the material. Text should be generally well-organized and coherent, using a variety of linking words and cohesive devices.

\subsubsection{Grammar}

Grammar is an important part in the ability to use language successfully. For this reason, grammar has been considered as an essential element in the success of writing task. It is defined as "the rules that govern how language sentences are formed" (Thornbury, 2000:01). Wang (2010) adds "Grammar as a set of rules for choosing words and putting words together to make sense" (78). It means the rules that decide the correct order and usage of the elements of a language. Mastering of grammar is not an easy task for the students. That Widodo (2006:112) states "without a good knowledge of grammar, learners' language development will be severely constrained." This requires writing in a comprehensible and clear way, which means to know the rule and how to use it correctly.

The lack of grammatical competence become crucial problem in writing; and this make us notice that most of EFL students make various errors, which Al-buainain (2009:04) claims that "Sentence-level grammatical errors committed by the learners involve some syntactic features, namely verbs, relative clauses, articles, fragments, noun modifiers, and prepositions". For instance, students fail to select the right tense form to share their thoughts or do not conjugate it right. Also they possibly do not select the right articles a/the or miss order the structure of sentences. According to Hui-mien Tan (2007) confirm that " it will be very difficult to compose a clear, logical and fluent paragraph if a writer is unable to write reasonably acceptable simple sentences and does not possess the mastery of some complex sentence structures" (177). So, this error hinders the understanding of what they want to convey and fail to write in a correct way.

\subsubsection{Content}

The content deals with how of the idea in writing. The more ideas students have the more writing they produce. One way of generating ideas is group discussion which can be taken place in the form of cooperative learning that is why cooperative, not competitive or individualistic learning, is rich with ideas.

\subsubsection{Vocabulary}

Vocabulary has a great influence on the student's comprehension, which has been recognized as an important aspect of language components. According to Helena Fortes (2007:9) "vocabulary is one of the main keys for successful communication in language". Learning vocabulary has a critical part in language and it has also been regarded an essential element in the context and writing process. Similarly, Alamirew, [1] says, "A good writing or composition should consist of appropriate and varied range of vocabularies used along with proper grammar and varied range of sentence structures." Vocabulary plays an important role in writing, because it is the basic component of language. But it's classified as one of the main difficulties in writing skill. When the students lack this skill, they fail to produce in-depth word knowledge, also their piece of writing they contain unfamiliar words which reflect the reader comprehension and the purpose of writing to get the actions or information they want. They also impacted their ability to write English correctly.

\subsubsection{Coherence and Cohesion}

Coherence and cohesion are writing elements that give meaningful sense for our writing. Coherence is the way in which ideas in a text are linked logically. Coherence in writing means that all the ideas in a paragraph flow smoothly from one sentence to the next sentence. To have this effect in writing, text should be logically sequenced, appropriately organized and easy to follow and understand with the effect of cohesion, inference, logical order and connectives.

Cohesion is linguistic connections and ties that exist between words and sentences to give structure to a text. Links between words, lexis, syntax, and phonology may all be used to create cohesion within and between sentences with the effects of factors such as information flow, anaphoric and cataphoric reference, deictic, repetition, synonym, antonym, hyponymy, collocation, ellipsis, substitution, conjunctions and adverbials. Thus, we have to use these elements in our writings to express our ideas easily and clearly.

\subsubsection{Mechanics of Writing}

Mechanics, according to this study, includes the spelling, punctuation and capitalization. Spelling is a basic skill in written expression which enables the writer to convey meanings and to communicate in a significant manner. Abdulmoneim (2013:06) states "Spelling is a language skill 
whereby sounds (phonemes) are represented by letters (graphemes) which constitute the smallest building blocks of written language". At every educational stage, students make mistakes in spelling. This difficulty causes a problem for students that make them confused about the relationship that exists between sound and speech. So, spelling process plays an important factor in writing skill.

\section{Research Design and Methodology}

\subsection{Research Design}

The design of this study was mainly experimental since it tries to find out the effect of cooperative learning on students' writing skills performance. This is because its goal is to determine the effect of the independent variable on the dependent variable under study. In this regard, the cooperative learning strategy was the independent variable, while student's writing performance was considered as the dependent variable. Using the quantitative data, test results, the researcher tried to see which components of the writing skill most benefited from the cooperative writing approach in writing class. Moreover, the quantitative data analyses employed SPSS packages like t-test, standard deviations and mean values.

\subsection{Data Sources}

The participants and data sources of this study were Grade 11 students of samara secondary and preparatory school.

\subsection{Sample and Sampling Techniques}

A simple random sampling technique used to choose a preparatory school for the study. To this end, Samara Secondary and Preparatory School was selected using the convenient sampling method. This technique was chosen because the researcher could easily select subjects based on their relative ease of access (Kumar, 1996). Since it is too large to handle both grades 11 and 12 in this study, the researcher delimited the grade level to grade 11. On one hand, it is manageable to look at specific grade level. On the other hand, grade 12 is busy of taking the entrance exam, for this reason they cannot fully involve in the study. Therefore, the sample grade level for this study was grade 11 students of the preparatory school.

\subsection{Data Gathering Methods}

In this study, the writing test was used as data gathering method. The experiment investigated the effects of cooperative learning on students' writing performance. Furthermore, the test result was also used to identify the component that most benefited from the cooperative writing approach.

\subsubsection{Conducting the Experiment}

After assigning the groups into control and experimental, the pre-test of writing performance questions was given to both of them. Both experimental and control group students took the pre-test for 80 minutes i.e. for two consecutive periods.
Then, the experimental group received progressive treatments how to use cooperative learning approach for effective writing performance and continued learning writing skill through the cooperative learning approach. But, the control group remained learning writing as usual which could be individually. During the treatment, there was the researcher's follow-up i.e. attending each class and commenting the teacher how to handle the classes and sometimes the researcher has recorded the progress. Finally, the post-test writing question was given for both of them. This then, based on their results, the analysis was made. Both the pre-test and post-test results checked by two raters. The assessment method to rate students writing tests was Paulus' (1999) the essay scoring rubric, which contains organization, development, grammar, cohesion \& coherence and mechanics of writing which includes punctuations, capitalization and spelling.

\subsubsection{Writing Tasks}

The writing tasks which mainly consisted of paragraph and essay writing was prepared and used during the experiment for both control and experimental groups to support the writing exercises in the textbook. The tasks mainly based on Grade 11 English textbook and international ELT resource books. The tasks were mainly focused on paragraph and essay writing as they give students an opportunity to practice writing in detail. When the experimental group learned the tasks using the cooperative learning approach which encourages cooperative writing, the control group learned using the traditional approach which encourages writing alone.

\subsubsection{The Pre-test}

The main objective of the pre- test administered before the experiment was to find out if there was any significant difference in the writing performance between the experimental group and the control group in their writing abilities. The pre-test was the same for both groups, and it has three parts. The first part is a summary writing, which is a free writing. The second part a paragraph writing which is on guided writing. In this part the students were given information, and asked to write a paragraph using the information. The third part is also free writing. In this part, the students were given a topic and they were asked to write an essay on their own. The time given for the pre-test was one hour and twenty minutes i.e. taking two consecutive periods having forty minutes.

\subsubsection{The Post test}

At the end of the experiment, a post-test was given in order to find out if there was any significant difference between the control and the experimental groups in their writing abilities as a consequence of the experiment. As in the pre-test, the post-test was also classified into three parts. The first part is a summary writing which is a free writing. The second part is a paragraph writing which was a guided writing and the third part was essay writing which was free writing were administered to both groups. The time given for the post-test was one hour and twenty minutes i.e. taking two consecutive periods having forty minutes. 


\section{Results and Discussion}

\subsection{Introduction}

As mentioned earlier, the researcher conducted two hours twice a week (a total of about 16 hours) for eight weeks from $15^{\text {th }}$ October to $13^{\text {th }}$ December/2019 by integrating additional writing tasks for both groups. The control group was taught for two hours twice a week using the writing tasks from the Grade 11 textbook, which is currently in use and additional writing tasks prepared by the researcher. When the experimental group learned writing skills using the cooperative learning techniques with the researcher's supervision, the control group learned the writing exercises using the traditional approach.

\subsection{Results of the Pre-test and Post-test}

One of the basic research questions was asked whether or not cooperative learning approach improve students' writing performance. As already indicated, a pre-test was given before the experiment to all students (in both experimental and control groups). After they were taught for about 8 weeks with or without the cooperative learning approach, they were given the post-test. The results are presented by taking the average scores and the independent samples t-test and the paired samples t-test were computed using SPSS version 25.

Table 1.Results of Statistical Analysis of Independent Samples T-test in Pre and Post- test in Control and Experimental Group.

\begin{tabular}{|c|c|c|c|c|c|c|c|c|c|c|c|}
\hline \multirow{2}{*}{ Test } & \multicolumn{3}{|c|}{ Control Group } & \multicolumn{3}{|c|}{ Experimental Group } & \multirow{2}{*}{$\mathbf{D} / \mathbf{f}$} & \multirow{2}{*}{ Sig. } & \multirow{2}{*}{ t-value } & \multirow{2}{*}{ p-value } & \multirow{2}{*}{ Significance } \\
\hline & $\mathbf{N}$ & Mean Score & SD & $\mathbf{N}$ & Mean Score & SD & & & & & \\
\hline Pre-test & 30 & 20.51 & 4.38 & 30 & 20.43 & 5.12 & 58 & 0.264 & 0.068 & 0.946 & No significant difference \\
\hline Post-test & 30 & 19.76 & 4.28 & 30 & 28.96 & 4.33 & 58 & 0.761 & -8.266 & 0.000 & Significant difference \\
\hline
\end{tabular}

Table 1 above indicates the average scores of Samara Secondary and Preparatory School Control and Experimental groups in pre and post-tests. As shown above, the average mean scores of the Control group of 30 and the Experimental group of 30 students are 20.51 and 20.43 respectively for the pre-test. The standard deviation of the control group and experimental group is computed as 4.38 and 5.12 respectively for the pre-test. At the sig. 0.264, the t-value is 0.068 and the probability value (P-value) is 0.946 . Therefore, the difference between the above two scores was found to be statistically insignificant difference over its pre-test compared to that of the control group $(\mathrm{P}>0.05$ i.e. 0.946). This result also confirmed that this two natural classes of Grade 11, which are assigned as control and experimental group have the same level of writing ability at the first time i.e. at a pre-test.

As can be seen from the above table, the average mean scores of the control and experimental groups of 30 students each are 19.76 and 28.96 respectively for the post-test. The standard deviation of the Control and Experimental groups in post-test is computed as 4.28 and 4.33 respectively. Besides the t-value is -8.266 , the P-value is below 0.05 (i.e. 0.000). Thus, post-test scores were found to be statistically significant indicating that the Experimental group made significant improvement over its post-test compared to the control group.

Therefore, the findings of the tests seem to indicate that cooperative learning approach had considerable contribution in enhancing students' writing performance. The researcher believes that since Grade 11 students are preparing themselves for universities and colleges, they need to learn writing using the cooperative learning approach to improve their writing. The results gained from interviews and questionnaire also confirmed that students liked learning writing using the cooperative learning approach. In this connection, Harmer (2006) also believes that writing in groups is effective in genre-based and process approach. Students found the activity motivating in terms of the writing itself. They also found the activity to be motivating when they embark on the research, discussed on the topics, had peer evaluation and achieved the group's goal.

Table 2. Results of Statistical Analysis of Paired Sample T-test in Pre and Post- tests of Control and Experimental Group.

\begin{tabular}{|c|c|c|c|c|c|c|c|c|c|c|c|}
\hline \multirow{2}{*}{ Group } & \multicolumn{3}{|c|}{ Pre-test } & \multicolumn{3}{|c|}{ Post-test } & \multirow{2}{*}{$\mathbf{D} / \mathbf{f}$} & \multirow{2}{*}{ Sig. } & \multirow{2}{*}{ t-value } & \multirow{2}{*}{ p-value } & \multirow{2}{*}{ Significance } \\
\hline & $\mathbf{N}$ & Mean Score & SD & $\mathbf{N}$ & Mean Score & SD & & & & & \\
\hline Control Group & 30 & 20.43 & 5.12 & 30 & 19.76 & 4.28 & 29 & 0.034 & 0.695 & 0.493 & No significant difference \\
\hline Experimental Group & 30 & 20.51 & 4.38 & 30 & 28.96 & 4.33 & 29 & 0.569 & -7.949 & 0.000 & Significant difference \\
\hline
\end{tabular}

In conclusion, this study lends credence to the belief that cooperative learning has positive effects on the students' writing performance. Therefore, the teacher should consider this learning approach as a viable alternative for the students in teaching writing.

As it is shown in the above table, a paired samples t-test was conducted to evaluate the effect of learning writing through cooperative learning techniques on students' writing performance.
Table 2 above indicates the correlated sample t-test of Samara Secondary and Preparatory School control group in pre-test against Samara Secondary and Preparatory School control group in post-test and Samara Secondary and Preparatory School Experimental group in pre-test against Samara Secondary and Preparatory School Experimental group in post-test. The correlated sample t-test table shows that the average scores of Samara Secondary and Preparatory School control group of 30 students are 20.43 and 19.76 for 
the pre-and post-tests respectively. The standard deviation of the control group is computed as 5.12 and 4.28 for the preand post-tests respectively. Regarding the $\mathrm{t}$-value and the $\mathrm{P}$ value, the t-value is 0.695 and the $\mathrm{P}$-value is 0.493 . The difference between the above two scores was found to be statistically insignificant. This indicates that the post-test mean scores of the control group showed no significant difference over the pre-test results. Thus, the control group even if they were taught writing using the tasks on the textbook and the supporting tasks prepared by the researcher did not improve their writing abilities.

The average scores of Samara Secondary and Preparatory School Experimental groups of 30 students are 20.51 and 28.96 for the pre-and post-tests respectively. The standard deviation of the Experimental group is computed as 4.38 and 4.33 for the pre-and post-tests respectively. Besides the above table shows that the t-value is -7.949 and the $p$-value is 0.000 . Thus, the experimental group made higher gains in writing performance in post-test scores as a result of using cooperative learning approach in the context of writing tasks. As shown in the literature reviewed in this study, the studies conducted on the incorporation of cooperative learning in learning writing showed that cooperative learning is an effective educational approach to improve the students' achievement in writing.

Similarly, Gillies [21] investigated whether teachers who implement cooperative learning engage in more facilitative interactions with their students than teachers who implement group work only. It has been emphasized that students can learn best in more learner-centered, collaborative settings as opposed to individual-oriented and competitive settings.

Table 3. Pre-test Results of the Basic Components of Writing.

\begin{tabular}{|c|c|c|c|c|c|c|}
\hline Items & Organization & Grammar & Content & Vocabulary & Coherence and cohesion & Mechanics of writing \\
\hline 1 & 6.5 & 5.5 & 5 & 6 & 4 & 4 \\
\hline 2 & 6.5 & 5.5 & 5 & 6 & 4 & 4 \\
\hline 3 & 6.5 & 5.5 & 4 & 5 & 4 & 4 \\
\hline 4 & 4.5 & 3.5 & 4 & 5 & 4 & 4 \\
\hline 5 & 3.5 & 4.5 & 3 & 4 & 4 & 4 \\
\hline 6 & 7.5 & 6.5 & 7 & 7 & 6 & 6 \\
\hline 7 & 3.5 & 3.5 & 3.5 & 3.5 & 4 & 4 \\
\hline 8 & 3.5 & 4 & 3 & 4.5 & 4 & 4 \\
\hline 9 & 6.5 & 5.5 & 4 & 3 & 4 & 4 \\
\hline 10 & 2.5 & 3 & 4.5 & 3 & 4 & 4 \\
\hline 11 & 4.5 & 4 & 3.5 & 3 & 4 & 4 \\
\hline 12 & 5.5 & 4 & 3.5 & 2 & 2 & 4 \\
\hline 13 & 3.5 & 3 & 2.5 & 1.5 & 2 & 4 \\
\hline 14 & 6.5 & 5.5 & 6 & 4 & 4 & 4 \\
\hline 15 & 4.5 & 3 & 2.5 & 3 & 4 & 4 \\
\hline 16 & 3.5 & 4 & 3 & 2 & 4 & 4 \\
\hline 17 & 4.5 & 3.5 & 3 & 2 & 2 & 4 \\
\hline 18 & 6.5 & 5.5 & 4 & 3 & 4 & 4 \\
\hline 19 & 3.5 & 3 & 3.5 & 2 & 2 & 2 \\
\hline 20 & 4.5 & 5.5 & 4 & 3 & 4 & 4 \\
\hline 21 & 4.5 & 3.5 & 3 & 4 & 4 & 4 \\
\hline 22 & 4.5 & 3.5 & 4 & 3 & 4 & 4 \\
\hline 23 & 6.5 & 5.5 & 4 & 3 & 4 & 4 \\
\hline 24 & 5.5 & 4.5 & 4.5 & 3.5 & 4 & 4 \\
\hline 25 & 4.5 & 3.5 & 2 & 3 & 2 & 4 \\
\hline 26 & 5.5 & 4.5 & 3 & 2 & 2 & 4 \\
\hline 27 & 5 & 4 & 3.5 & 2.5 & 2 & 4 \\
\hline 28 & 5.5 & 4.5 & 5 & 6 & 6 & 4 \\
\hline 29 & 5 & 5 & 3.5 & 3.5 & 3 & 4 \\
\hline 30 & 4.5 & 4 & 3 & 4 & 4 & 3 \\
\hline Total & 149 & 130.5 & 114 & 107 & 109 & 119 \\
\hline
\end{tabular}

Table 4. Post-test Results of the Basic Components of Writing.

\begin{tabular}{lllllll}
\hline Items & Organization & Grammar & Content & Vocabulary & Coherence and cohesion & Mechanics of writing \\
\hline 1 & 6.5 & 6.5 & 6.5 & 6 & 6 & 6 \\
2 & 6.5 & 6.5 & 6 & 6 & 6 & 6 \\
3 & 5.5 & 5.5 & 5 & 6.5 & 6 & 6 \\
4 & 7.5 & 6.5 & 6 & 8 & 8 & 6 \\
5 & 7.5 & 6.5 & 7 & 6 & 6 & 6 \\
6 & 6.5 & 5.5 & 6 & 5 & 6 & 6 \\
7 & 8.5 & 7.5 & 6.5 & 5 & 6 & 6 \\
8 & 5.5 & 4.5 & 4 & 5 & 6 & 6 \\
9 & 6.5 & 5 & 5.5 & 7 & 6 & 8 \\
10 & 4.5 & 5.5 & 6.5 & 6 & 6 & 6 \\
11 & 4.5 & 5 & 6 & 5.5 & 6 & 6 \\
\hline
\end{tabular}




\begin{tabular}{lllllll}
\hline Items & Organization & Grammar & Content & Vocabulary & Coherence and cohesion & Mechanics of writing \\
\hline 12 & 5.5 & 5 & 6 & 3.5 & 6 & 4 \\
13 & 6.5 & 5.5 & 5 & 6 & 6 & 6 \\
14 & 4 & 5 & 4 & 5 & 5 & 5 \\
15 & 4.5 & 5 & 6 & 4 & 4 & 4 \\
16 & 7 & 6 & 5.5 & 4.5 & 5 & 4 \\
17 & 4.5 & 5 & 4 & 4.5 & 6 & 4 \\
18 & 6.5 & 5 & 4 & 5.5 & 6 & 6 \\
19 & 4.5 & 4 & 5.5 & 5 & 6 & 6 \\
20 & 6 & 5 & 4.5 & 3.5 & 3 & 4 \\
21 & 6 & 5 & 4 & 2.5 & 2 & 4 \\
22 & 7.5 & 6.5 & 7.5 & 7 & 8 & 6 \\
23 & 7 & 6 & 6.5 & 6 & 7 & 6 \\
24 & 7 & 6 & 5 & 4.5 & 6.5 & 6 \\
25 & 7.5 & 6.5 & 6 & 7 & 8 & 5 \\
26 & 6.5 & 5.5 & 4 & 3 & 5 & 6 \\
27 & 7.5 & 7 & 6 & 7 & 8 & 6 \\
28 & 7.5 & 6 & 7 & 5.5 & 6 & 7 \\
29 & 7.5 & 6.5 & 6 & 6 & 8 & \\
30 & 7.5 & 6.5 & 7 & 6 & 8 & \\
Total & 190 & 171.5 & 168.5 & 162 & 181.5 & \\
\end{tabular}

\subsection{Results of the Basic Components of Writing}

A good composition should consist of the six basic components of writing mentioned in the literature and used to assess the students' writing which are organization, grammar, content, vocabulary, coherence \& cohesion and mechanics of writing. Similarly, Alamirew, [1] states a good composition should consist an appropriate and range of vocabularies used along with proper grammar and varied range of sentence structures.

Thus, at any level, written communication is more effective when all the basic components of writing achieved successfully in the work. In the following tables and description, the study tried to show which one of the components most benefited from the cooperative learning approach.

The composite scores above indicated that the students in the experimental group performed better in the post-test compared to the pre-test in terms of all the six components of writing(organization, grammar, content, vocabulary, coherence \& cohesion and mechanics of writing). The range of marks for the pre-test in organization was between 2.5 to 7.5 whereas for the post-test, the range of marks was between 4 to 8.5 . This showed that there was a notable difference between the minimum scores and the maximum scores. Similarly, the total mark 149 in the pre-test and 190 in the post-test in which the increase is $41 \%$ showed that after the incorporation of cooperative learning, the students were able to perform better in their writing regarding the organizing their ideas.

In terms of grammar, the range of marks for the pre-test was 3 to 6.5 whereas the range of marks for the post-test was 4 to 7.5 . This indicated that the minimum mark for grammar increased by 1 mark $(10 \%)$ whereas the maximum mark was enhanced by 1 mark (10\%). Similarly, the total mark 130.5 in the pre-test and 171.5 in the post-test in which the increase is $41 \%$ showed that after the incorporation of cooperative learning, the students were able to perform better in their writing regarding the grammar. Thus, the students' performance in writing in terms of grammar had increased after the incorporation of cooperative learning. This proved that students were able to write more grammatically accurate sentences and had better control of the structures after the inclusion of cooperative learning.

For content, the range of marks for the pre-test was 2 to 7 whereas the range of marks for the post-test was 4 to 7.5. This indicated that the minimum mark for content increased by 2 marks $(20 \%)$ whereas the maximum mark enhanced by 0.5 mark (5\%).In addition to this, the total marks 114 in the pre-test and 168.5 in the post-test with the increase of $54 \%$ indicated that the students performed better in the content component in their writing after they were taught using the cooperative learning approach.

In terms of vocabulary, the range of marks for the post-test was 2.5 to 8 whereas the range of marks for the pre-test was 1.5 to 7 . This indicated that the minimum mark for vocabulary increased by 1 mark $(10 \%)$ and the maximum mark was enhanced by 1 mark $(10 \%)$. Furthermore, the total marks 107 in the pre-test and 162 in the post-test with the increase of $55 \%$ showed that the students' performance in writing in terms of vocabulary had been enhanced after the inclusion of cooperative learning. This proved that when the students experienced cooperative learning in their writing classes, they were able to generate more apt and appropriate vocabulary in their writing for their writing.

For coherence and cohesion, the range of marks for the pre-test was 2 to 6 whereas the range of marks for the posttest was 2 to 8 . This indicated that even though there was no change in the minimum mark for coherence and cohesion, the maximum mark enhanced by 6 marks $(60 \%)$.In addition to this, the total marks 109 in the pre-test and 181.5 in the posttest with the increase of $72.5 \%$ indicated that the students performed better in the coherence and cohesion component in their writing after they were taught using the cooperative learning approach.

In terms of mechanics of writing, the range of marks for the 
post-test was 4 to 8 whereas the range of marks for the pre-test was 2 to 6 . This indicated that the minimum mark for vocabulary increased by 2 marks $(20 \%)$ and the maximum marks were enhanced by 4 marks $(40 \%)$. Furthermore, the total marks 119 in the pre-test and 170 in the post-test with the increase of $51 \%$ showed that the students' performance in writing in terms of coherence and cohesion had been enhanced after the inclusion of cooperative learning. This proved that when the students experienced cooperative learning in their writing classes, they were able to generate more apt and appropriate discourse features in their writing. This proved that students were able to spell words better and made less error with punctuations after experiencing of cooperative learning.

As mentioned above, the study showed an improvement in all the writing components in the results of the post-test. When we look at the research question, which one of the components of writing benefits most from the cooperative learning, looking at the total marks in the post-test that are organization (190), grammar (171.5), content (168.5), vocabulary (162), coherence and cohesion (181.5) and mechanics of writing (170) indicated that organization was the writing component that students most benefited from the cooperative learning approach.

\section{Conclusions}

Based on the results and discussion of the study, the following conclusions were made. The pre-test and post-test results were the core data used in this study. A T-test was used to compare the average scores of the control and experimental groups. The results of the pre-test showed that there was no significant difference between the average scores of the control and the experimental groups at 0.05 level of significance (See table 1 and 2). The results of the statistical analysis of the independent sample test in the posttest showed that the students in the experimental groups improved their writing performance $(\mathrm{P}<0.05)$ at 0.05 level of significance. This implies that cooperative learning approach in the context of writing did improve the students' writing abilities. Similarly, the pre-test and post-test results of the basic components of writing also showed that organization is the component that most benefited from the cooperative learning approach.

\section{References}

[1] Alamirew G/Mariam (2005). A Study on the Perception of Writing, Writing Instruction, and Students' Writing Performance. Unpublished Ph.D. Thesis, Addis Ababa University.

[2] Brown (2000).Teaching by Principles: An Interactive Approach to Language Pedagogy. Longman. California.

[3] Brown, H. Douglas, (1941). Principles of Language Learning and Teaching. Longman. California.

[4] Brown, H. Douglas, (2000). Teaching by Principles: An Interactive Approach to Language Pedagogy ( $2^{\text {nd }}$ edn). Longman. California.
[5] Brown, H. D. (2001). Teaching by principles: An interactive approach to language pedagogy (2nd ed.). New York: Addison Wesley Longman.

[6] Brown, D., and Thomson, C (2000).Cooperative Learning in New Zealand Schools, Palmerston, NZ: Dunmore Press.

[7] Crandall, (1999).Cooperative language learning and affective factors. CUP.

[8] Christison, M.A. (1990). Cooperative learning in the EFL classroom. English language forum.

[9] Cohen, E. (1994a). Designing group work: Strategies for the heterogeneous classroom.(2nd Edition). New York: Teachers College Press.

[10] Cohen, L. (2000) Research Methods in Education ( $5^{\text {th }}$ Edn). London: Routledge Falmer

[11] Cohen, E.G., \& Lotan R, A. (2014). Designing group work strategies for the heterogeneous classroom(3rd ed.). New York, NY: Teachers College Press.

[12] Creswell, J., Klassen, A., Clark, V., and Smith, K. (2010). Best Practices for Mixed Methods Research in the Health Sciences. The Office of Behavioral and Social Sciences Research (OBSS).

[13] Creswell, J. W. (2014). Research design: Qualitative, Quantitative, and Mixed Methods Approaches. Los Angeles: SAGE Publications.

[14] Cronbach, L. J. (1951). Coefficient alpha and the internal structure of tests. Psychometrika, 16(3), 197-334.

[15] Dorneyi, Z. (2007). Research Methods in Applied Linguistics. Oxford University Press.

[16] Ebrahim, A. (2012). The effect of cooperative learning strategies on elementary students' science achievement and social skills in Kuwait. International Journal of Science and Mathematics Education, 10, 293-314.

[17] Effandi, Z., \& Zanaton, I. (2007). Promoting cooperative learning in science and mathematics education: A Malaysian perspective. Eurasia Journal of Mathematics, Science \& Technology Education.

[18] Ellis, R. (2003). Task-based Language Learning and Teaching. Oxford: Oxford University Press.

[19] Galton, M., and Williamson, J. (1992).Group work in the Primary Schools, London, Routledge.

[20] Gillies, R., \& Ashman, A. (1996).Teaching collaborative skills to primary school children in classroom-based work groups. Learning and Instruction, 6, 187-200.

[21] Gillies, R. (2006). Teachers' and students' verbal behaviors during cooperative and small-group learning. British Journal of Educational Psychology, 76, 271-287.

[22] Goodyear, P., Banks, S., Hodgson, V., and McConnell, D. (2004). Advances in Research on Networked Learning. Instructional Science, 31(1-2), 1-6.

[23] Hamidah, C. M. (2008). The Impact Study on the Performance of Critical Thinking Skills in Writing a Summary of the Subject of Malay Language among Students of Different Levels of Achievement. MA Thesis, Serdang, Malaysia. 
[24] Haregewoin Abate (2008).The Effect of Communicative Grammar on the Grammatical Accuracy of Students Writing: An Integrated Approach to TEFL. Unpublished Ph.D. Thesis. AAU.

[25] Harmer, J. (2004). How to teach writing. Harlow: Longman.

[26] Harmer, J. (2005). How to teach English. An introduction to the practice of English language teaching. Addison Wesley Longman Limited. (First Pub 1998).

[27] Harmer, J. (2006).The practice of English language teaching. England: Pearson.

[28] Harris, J. (1993). Introducing Writing. England.

[29] Hayes. (1996). A new framework for understanding cognition and affect in writing. In C.M. Levy and S. Randell (eds), The science of writing. NJL Lawrence Erlbaum Associates

[30] Hedge, T. (2000). Teaching and learning in the language classroom. Oxford: Oxford University Press.

[31] Hedge,T.(2005).Writing. Oxford: Oxford University Press.

[32] Hertz-Lazarowitz, R. (1989). Cooperation and helping in the classroom: A contextual Approach. International Journal of Educational Research, 13, 113-119.

[33] Hogan, T.P., Benjamin, A., \& Brezinksi, K.L. (2000). Reliability methods: A note on the frequency of use of various types. Educational and Psychological Measurement, 60(4), 523-531.

[34] Hornby, G. (2009). The effectiveness of cooperative learning with trainee teachers. Journal of Education for Teaching: International research and pedagogy, 35, 161-168.

[35] Ismail, S.A. (2007). Exploring students' perceptions of ESL writing. English language teaching, 4(2)

[36] Italo Beriso (1999). A Comparison of the Effectiveness of Teacher versus Peer Feedback on Addis Ababa University Students' Writing Revisions. Ph.D. Thesis, AAU.

[37] Johns (2003). 'Genre and ESL/EFL Composition Instruction' In Exploring the Dynamics of Second Language Writing, Barbara Kroll (Ed.) 195-217 Cambridge: Cambridge University Press.

[38] Johnson, R.T., and Johnson, D.W. (1986).Action research: Cooperative learning in the science classroom. Science and children, 24, 31-32.

[39] Johnson, D. W. \& Johnson, R. T., (1989).Cooperation and Competition: Theory and Research. Interaction Book Company.

[40] Johnson, D. and Johnson, R.T. (2003). Students Motivation in Cooperative Groups. Cooperative Learning the Social and Intellectual. Outcomes of Learning in Groups. London: Routledge Flamer.

[41] Johnson, D. W., Johnson, R. T. and Holubec, E.J.(1994). Cooperative Learning in the Classroom, Alexandria, VA, ASCD.

[42] Johnson et al (1998). Cooperation in the Classroom, Edina, $\mathrm{MN}$, Interaction Book Company.

[43] Johnson, D. W., \& Johnson, R. (1999).Learning together and alone: Competitive and Individualistic Learning. Needham Heights: Allyn \& Bacon.
[44] Johnson, D. W., Johnson, R. T., \& Stanne, M. B. (2000). Cooperative learning methods: A meta-analysis. Retrieved on April 18, 2017, from http://www.cooperation org/pages/clmethods.html

[45] Johnson, D. W., Johnson, R., \& Smith, K. (2007). The state of cooperative learning in Postsecondary and professional settings. Educational Psychology Review, 19, 15- 29.

[46] Johnson, D. W. \& Johnson, R. T. (2009).An Educational Psychology Success Story: Social Interdependence Theory and Cooperative Learning. Educational Researcher, 38, 365379

[47] Kagan, S. (2001).Cooperative Learning. Kagan Publishing.

[48] Kagan, S., \& Kagan, M. (2009). Kagan cooperative learning. San Clemente: Author.

[49] Kagan, S. \& High, J. (2002). Kagan structures for English language learners. Retrieved from: December 9, 2018, http:www.KaganOnline. Com.

[50] Kumar, R. (2001). Research Methodology: A Step-by-Step Guide for Beginner. London: Addison Wesley Longman.

[51] Kyndt, et al. (2013). A meta-analysis of the effects of face-toface cooperative learning. Do recent studies falsify or verify earlier findings? Educational Research Review, 133-149.

[52] Law, Y. K. (2011). The effects of cooperative learning on enhancing Hong-Kong fifth graders' achievement goals, autonomous motivation and reading proficiency. Journal of Research in Reading, 34(4), 402-425.

[53] Lee, H. (2009). Group learning and cooperative learning in English language teaching.(Master's thesis). Shandong Normal University, JINan, China.

[54] Liang, T. (2002). Implementing cooperative learning in EFL teaching: Process and effects. Doctoral Dissertation, National Taiwan Normal University, Taipei, Taiwan.

[55] Lotan, R. (2003). Group worthy tasks: When four heads are better than one. Educational Leadership,

[56] Maasum, M. T. (2010). The Effects of cooperative learning in enhancing writing performance. Malaysia: SyafiniBt

[57] Mandal, R. R. (2009).Cooperative learning strategies to enhance writing. The Modern of Applied Linguistics.1 (2).

[58] Matthews, R. S., Cooper, J., Davidson, N., \& Hawkes P., (1995). Building Bridges between Cooperative and Collaborative Learning. Change, 27, 35-40.

[59] McDonough, J. and Shaw, C. (1993).Materials and Methods in ELT. Blackwell.

[60] Millis, B. J. (2010). Cooperative Learning in Higher Education: Across the Disciplines, Across the Academy. Stylus Publishing.

[61] Millis, B. J., \& Cottell, P. G. (1998).Cooperative learning for Higher Education Faculty. Phoenix.

[62] MoE,(1994). Transitional Government of Ethiopia Education and Training Policy, Addis Ababa.

[63] Slavin, R. E. (1983a). Cooperative learning. New York: Longman. 
[64] Slavin, R. E. (1989). Research on Cooperative Learning: Consensus and Controversy. Educational Leadership, 47, 5254.

[65] Slavin, R. E. (1994).Cooperative learning: theory, research, and practice. $\left(2^{\text {nd }} E d.\right)$ Pearson.

[66] Slavin, R. E. (1995). Cooperative learning (2nd ed.). Boston: Allyn\& Bacon.
[67] Slavin, R. E. (2015). Cooperative learning in elementary schools. Education. International Journal of Primary, Elementary and Early Years Education, 43(1), 3-13

[68] Zhang, X., \& Chen, J. (1989).The techniques to teaching writing. English Teaching Forum, 27(2), 34.

[69] Zhou, H. (2012). Enhancing non-english majors' EFL motivation through cooperative learning. Procedia Environmental Sciences, 12(1), 1317-1323. 